\title{
Profile and Prediction of Severity of Rheumatic Mitral Stenosis in Children
}

\author{
Ismet N. Oesman, Hartono Gunardi, Bambang Madiyono, Sudigdo Sastroasmoro, Sukman Tulus Putra
}

\begin{abstract}
Abstrak
Di negara-negara berkembang seperti Indonesia, penyakit jantung reumatik (PJR) masih merupakan masalah kesehatan masyarakat. Stenosis mitral reumatik (SMR) dapat terjadi dengan cepat dan SMR berat dapat timbul pada umur sedini 15 tahun di negara Asia-Afrika. Pemeriksaan fisik tidak cukup akurat untuk menentukan derajat berat SMR. Penelitian ini untuk mengetahui gambaran klinis SMR pada anak, gambaran EKG dan foto Roentgen dada yang mungkin dapat memperkirakan derajat berat SMR sesuai ekokardiografi. Telah dilakukan penelitian 'cross-sectional' pada 28 pasien SMR di Bagian Ilmu Kesehatan Anak RSCM. Umur rata-rata adalah 13,5 tahun. Dua pasien tidak dapat disertakan dalain uji diagnostik karena pemeriksaan yang belum lengkap. Derajat berat SMR berdasarkan pengukuran luas katup mitral dengan ekokardiografi $2 \mathrm{D}$ digolongkan dalam derajat ringan, sedang dan berat masing-masing terdapat pada 1, 15 dan 10 pasien. Prakiraan derajat berat SMR berdasarkan RVH dan RAD pada EKG menunjukan spesifisitas $75 \%$ dan nilai duga negatif $85,7 \%$. Prakiraan derajat berat SMR berdasarkan analisis foto Roentgen dada menunjukkan sensitifitas $80 \%$, spesifisitas $81,2 \%$ sedangkan nilai duga negatifadalah $86,7 \%$. Kombinasi pemeriksaan EKG atau Foto Roentgen dada menunjukan sensitifitas yang tinggi yaitu 90\%, yang berguna untuk menapis pasien SMR di daerah yang tidak mempunyai fasilitas ekokardiografi. Nilai duga negatif pemeriksaan kombinasi adalah $92 \%$, yang berarti bila tidak didapatkan tanda SMR berat pada EKG atau foto Roentgen dada, kemungkinan besar bukan SMR berat.
\end{abstract}

\begin{abstract}
In developing countries such as Indonesia, rheumatic heart disease (RHD) is still an important community health problem. Rheumatic mitral stenosis (RMS) occurs more rapidly and severe RMS could occur at age as early as 15 years old in Asia-Africa country. The physical examination is not accurate enough to predict the severity of RMS. The aims of this study are to explore RMS clinical, $E C G, C X R$, echocardiographic features, and to evaluate the value of ECG or CXR as a diagnostic tool predict the RMS severity compared to echocardiography as a gold standard. Cross-sectional study was done on 28 RMS patients at Child Health Department Dr Cipto Mangunkusumo Hospital. Mean of age was 13.5 years. Unfortunately 2 patients were excluded from diagnostic test due to incomplete examination. The severity of RMS based on $2 \mathrm{D}$ echo was classified as mild, moderate and severe in 1, 15 and 10 patients, respectively. The specificity of RMS severity prediction by RVH and RAD on ECG was $75 \%$, and negative predictive value was $90.9 \%$. Sensitivity of CXR in prediction of RMS severity was $80 \%$, specificity was $81.2 \%$, while negative predictive value was $86.7 \%$. The combination of ECG or CXR gave $90 \%$ sensitivity that would be beneficial to screen RMS patient in rural area. The negative predictive value was $92 \%$. This means that if there is no severe RMS sign on ECG nor CXR, then the RMS is most probably not severe.
\end{abstract}

Keywords : Rheumatic mitral stenosis, mitral valve area, 2D-echocardiography

In developing countries as Indonesia, rheumatic fever (RF) and rheumatic heart disease (RHD) are still an important community health problem. RHD potentially raises serious problem for patient, family, community as well as our country, because it strikes young and productive people and may influence the future human resource. ${ }^{1}$ About one third of the children suffering from RF would have chronic sequel as RHD especially affecting the mitral valve which

Department of Child Health, Medical School University of Indonesia, Dr. Cipto Mangunkusumo Hospital, Jakarta, Indonesia occur at a frequency of $75-98 \% .^{2,3,4,5}$ Mitral abnormality could be manifested as regurgitation, stenosis or both. In developed countries rheumatic mitral stenosis (RMS) occurred at least 5 - 10 years after the acute episode of RF; ${ }^{6}$ but in developing countries, primarily in Asia Africa, RMS has more rapid clinical course and severe RMS could occur in patients at the age of 15 years. ${ }^{7}$ Generally, RMS raises more problems and needs for earlier intervention than rheumatic mitral regurgitation (RMR).

Data on characteristic, clinical, electro-cardiographic (ECG), roentgenographic (CXR) and echocardiographic features of RMS in Indonesian children are 
still rare in literature. The physical examination is not accurate enough to predict the severity of RMS. ${ }^{8}$ The ECG or CXR feature might be important as a diagnostic tool especially in predicting the RMS severity with certain accuracy as a reason to refer patient from rural area. The aims of this study are to evaluate the characteristic, clinical, ECG, CXR and echocardiographic features of RMS in Indonesian children; and to evaluate the value of ECG or CXR as a diagnostic tool to predict the RMS severity compared to echocardiography as a gold standard.

\section{METHODS}

This study was a cross-sectional study performed at The Child Health Department Dr Cipto Mangunkusumo Hospital, since December 1990 until April 1993. The inclusion criteria were patient's age among 4.5 - 18 years old and diastolic rumbling with presystolic accentuation at the apex. The exclusion criteria were (1) predominant mitral regurgitation, (2) other heart valve abnormalities which were more dominant such as severe aortic regurgitation (both criteria were excluded by clinical examination and supported by the presence of left ventricular hypertrophy $(\mathrm{LVH})$ on ECG), and (3) severe chronic pulmonary disease as such as bronchiectasis and destroyed lung.

The sample size was calculated by formula ${ }^{9}: N=$ ${ }^{4} \mathrm{Z}_{\alpha}{ }^{2} \mathrm{P}(1-\mathrm{P}): \mathrm{W}^{2} \cdot \mathrm{Z}_{\alpha}=$ the standard normal deviate for two tailed $\alpha$, in this study the confidence level was $90 \%$, so $\mathrm{Z}_{\alpha}=1.645 . \mathrm{P}=$ expected sensitivity/ specificity. $W=$ total width of confidence interval, in this study was 0.3 . $\mathrm{N}=$ sample size. If $\mathrm{P}$ was predicted as 0.7 , then $\mathrm{N}$ would be 26 .

The functional capacity of patients was classified according to The New York Heart Association (NYHA). ${ }^{10}$

The right ventricular hypertrophy (RVH) criteria on ECG were that used in the Pediatric Cardiology subdivision Child Health Department such as : $\mathrm{R}_{1}>\max$ (age $>30$ months : $\mathrm{R}_{1}>19 \mathrm{~mm}$ ), $\mathrm{S}_{6}>\max$ (age $>3$ months: $S_{6}>6 \mathrm{~mm}$ ), $\mathrm{R}_{1} / \mathrm{S}_{1}>\max$ (age $6-15$ years : $R_{1} / S_{1}>0.8$ ), $T$ wave positive in $V_{1}$ after the third day, if $R_{1} / S_{1}>1.0$. The right axis deviation (RAD) was considered if the QRS axis $>110^{\circ}$. The prediction of severe RMS was based on the presence of RVH and RAD.

The prediction of RMS severity by CXR with Barium contrast was as follows:
1. mild: (a) cardiac silhouette was normal, unless left atrial appendage (LAA) enlargement was seen on AP projection, 11 (b) left atrial (LA) enlargement was seen on lateral or left anterior oblique projection $^{12-14}$

2. moderate: mild criteria plus: (a) right ventricle enlargement, (b) moderate pulmonary hypertension: redistribution of pulmonary blood vessel (upper lobe $=$ lower lobe)

3. severe: moderate criteria plus: (a) right atrial enlargement, ${ }^{12,13}$ (b) severe pulmonary hypertension if any sign listed below was found: pulmonary artery trunk enlargement, ${ }^{12,13}$ pulmonary blood vessel of upper lobe lower lobe, ${ }^{7}$ Kerley A or B line, $^{12}$ alveolar oedema. ${ }^{5,7}$

The mitral valve orifice area (MVA) was measured by 2 D Toshiba Sonolayer echocardiography. The severity of RMS based on MVA was classified as follows: mild, if MVA was $2-2.5 \mathrm{~cm}^{2}$; moderate, if MVA was $1-2 \mathrm{~cm}^{2}$; severe, if MVA was less than 1 $\mathrm{cm}^{2}$.

The diagnostic tests of ECG and CXR were compared to MVA measurement of $2 \mathrm{D}$ echocardiography as gold standard. Diagnostic indices were sensitivity, specificity, positive predictive value, negative predictive value, and accuracy. Confidence interval (c.i.) of diagnostic indices was calculated by formula : ${ }^{15}$

$$
\text { c.i. }=\frac{2 p+\theta^{2} \pm \theta \sqrt{\theta^{2}+4 p(1-p)}}{2+2 \theta^{2}}
$$

p $\quad=$ proportion of diagnostic index

$\theta \quad=Z_{\alpha / 2}: \sqrt{ } \mathrm{N}$

$\mathrm{Z}_{\alpha / 2}=$ normal standard deviate for 2 tailed $\alpha$, in this study the confidence level was $90 \%$ so $Z_{\alpha / 2}=1.645$

\section{RESULTS}

\section{Patients' profile}

Mean age was 13.5 (SD 2.0) years (range : $10-18$ years). There were 15 male and 13 female patients. Mean weight was 32.48 (SD 8.35 ) kg. Mean height was 142.21 (SD 1.21$) \mathrm{cm}$. Functional capacity was classified according to NYHA. Class I, II and III were found in 9, 12 and 7 patients respectively. The mean haemoglobin level was 12.3 (SD 0.96) g/dl (range: $10.3-14 \mathrm{~g} / \mathrm{dl}$ ). Mean haematocrite was 37.1 (SD 2.5) vol\% (range : $32-42$ vol\%). 


\section{The ECG abnormalities}

The ECG abnormalities were shown on Table 1. Left atrial enlargement was found in 21 out of $26(80.77 \%)$ cases, while right ventricular enlargement was detected in 15 out of $26(57.69 \%)$ patients. Right axis deviation was found in 12 cases (46.15\%). Various ECG features of RMS patients according to RMS severity were shown in Table 4.

Table 1. ECG abnormalities in 26 RMS patients

\begin{tabular}{lrc}
\hline Abnormalities & Cases & $\%$ \\
\hline Right axis deviation & 12 & 46.15 \\
Rhythm : sinus tachycardia & 14 & 53.85 \\
$\quad$ atrial fibrillation & 3 & 11.54 \\
Left atrial enlargement & 21 & 80.77 \\
Right ventricular hypertrophy & 15 & 57.69 \\
Right atrial enlargement & 9 & 34.62 \\
\hline
\end{tabular}

\section{The CXR abnormalities}

The CXR abnormalities were seen in Table 2.

Severe RMS was found in in 11 out of $26(42.31 \%)$, while mild and moderate RMS were found in 15 out of $26(57.69 \%)$ patients.

Table 2. CXR abnormalities in RMS patients

\begin{tabular}{lrl}
\hline Abnormalities & Sum & $\%$ \\
\hline Left atrial appendix enlargement & 18 & 68.23 \\
Left atrial enlargement & 26 & 100 \\
Right atrial enlargement & 9 & 34.62 \\
Left ventricular enlargement & 15 & 57.69 \\
Right ventricular enlargement & 21 & 80.77 \\
Cardiomegaly & 23 & 88.46 \\
Pulmonary hypertension: & & \\
$\quad$ - moderate & 13 & 50 \\
$\quad$ - severe & 11 & 42.31 \\
Severity of RMS: & & \\
$\quad$ - mild & 2 & 7.69 \\
$\quad$ - moderate & 13 & 50 \\
$\quad$ - severe & 11 & 42.31 \\
\hline
\end{tabular}

\section{The $2 \mathrm{D}$ echocardiography}

The $2 \mathrm{D}$ echocardiography examination of RMS severity was shown in Table 3 . There were 10 severe RMS out of 26 patients ( $38.46 \%)$.
Table 3. RMS severity by 2-D echocardiography in 26 cases

\begin{tabular}{lrr}
\hline RMS severity & Cases & \multicolumn{1}{c}{$\%$} \\
\hline Mild & 1 & 3.85 \\
Moderate & 15 & 57.69 \\
Severe & 10 & 38.46 \\
\hline
\end{tabular}

Table 4. ECG features according to echographic RMS severity

\begin{tabular}{lcc}
\hline & $\begin{array}{c}\text { RMS severity by echocardiography } \\
\text { Severe }\end{array}$ & No severe \\
\hline LAE & 1 & 7 \\
RVH + RAD & 2 & 1 \\
LAE + RAVH + RAE + RAD & 4 & 3 \\
LAE + RAE & - & 2 \\
LAE + RVH & 1 & 1 \\
RVH & - & 1 \\
LAE + RVH + RAD & 2 & - \\
Normal & - & 1 \\
\hline Total cases & 10 & 16 \\
\hline
\end{tabular}

The RMS severity prediction by RVH and RAD on ECG

The sensitivity, specificity, predictive value and accuracy of RVH and RAD were shown in Table 5.

Table 5. Diagnostic indices of RVH and RAD on ECG and RMS severity

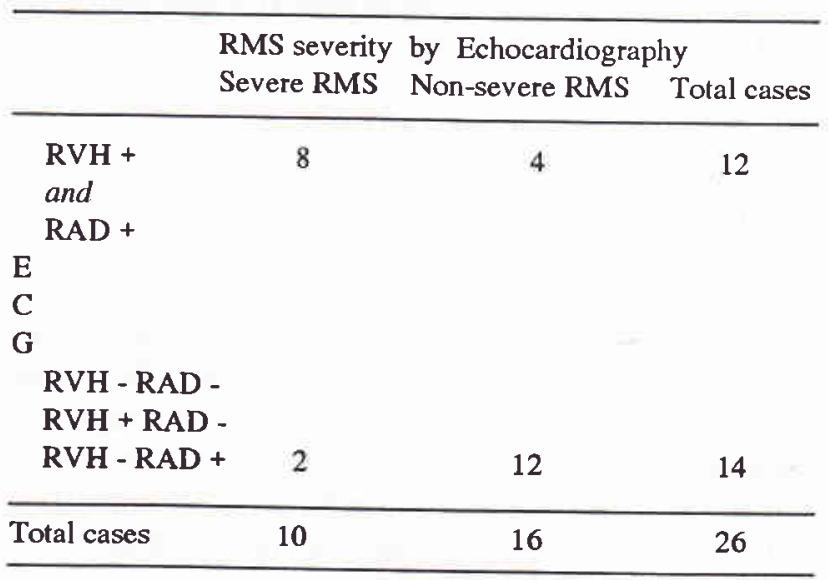

Sensitivity $=80 \% \quad$ (c.i. $90 \%: 65 \%$ to $90 \%$ )

Specificity $=75 \%$ (c.i. $90 \%: 59 \%$ to $86 \%$ )

Positive predictive value $=66.7 \%$ (c.i. $90 \%: 51 \%$ to $80 \%$ )

Negative predictive value $=85.7 \%$ (c.i. $90 \%: 71 \%$ to $94 \%$ )

Accuracy $=76.9 \%$ (c.i. $90 \%: 61 \%$ to $87 \%$ ) 


\section{The RMS severity prediction by CXR analysis}

The sensitivity, specificity, predictive value and accuracy of CXR analysis were shown in Table 6.

Table 6. Diagnostic index of CXR analysis and RMS severity

\begin{tabular}{lccc}
\hline & \multicolumn{3}{c}{ RMS severity by Echocardiography } \\
& Severe RMS & Non-severe RMS & Total cases \\
\hline $\begin{array}{l}\text { Severe } \\
\text { RMS }\end{array}$ & 8 & 3 & 11 \\
C & & & \\
X \\
R Non- \\
$\begin{array}{l}\text { severe } \\
\text { RMS }\end{array}$ & 2 & 13 & 15 \\
\hline Total cases & 10 & 16 & 26 \\
\hline
\end{tabular}

Sensitivity $=80 \%$ (c.i. $90 \%: 65 \%$ to $90 \%$ )

Specificity $=81.2 \%$ (c.i. $90 \%: 66 \%$ to $91 \%$ )

Positive predictive value $=72.7 \%$ (c.i. $90 \%: 57 \%$ to $84 \%$ )

Negative predictive value $=86.7 \%$ (c.i. $90 \%: 72 \%$ to $94 \%$ )

Accuracy $=80.8 \%$ (c.i. $90 \%: 65 \%$ to $90 \%$ )

\section{The RMS severity prediction by ECG or CXR} analysis

The sensitivity, specificity, predictive value and accuracy of ECG or CXR analysis were shown in Table 7.

Table 7. Diagnostic index of ECG or CXR analysis and RMS severity

\begin{tabular}{lccc}
\hline \multicolumn{4}{c}{ RMS severity by Echocardiography } \\
& Severe RMS & Non-severe RMS & Total cases \\
\hline $\begin{array}{l}\text { Severe } \\
\text { RMS }\end{array}$ & 9 & 5 & 16 \\
$\begin{array}{l}\text { ECG } \\
\text { or } \\
\begin{array}{l}\text { CXR } \\
\quad \text { Non- } \\
\text { severe }\end{array}\end{array}$ & & & \\
$\quad$ RMS & 1 & 11 & 10 \\
\hline Total & 10 & 16 & 26 \\
\hline
\end{tabular}

Sensitivity $=90 \%$ (c.i. $90 \%: 76 \%$ to $96 \%$ ).

Specificity $=69 \%$ (c.i. $90 \%: 53 \%$ to $81 \%$ ).

Positive predictive value $=64 \%$ (c.i. $90 \%: 48 \%$ to $77 \%$ ).

Negative predictive value $=92 \%$ (c.i. $90 \%: 79 \%$ to $97 \%$ ).

Accuracy $=77 \%$ (c.i. $90 \%: 61 \%$ to $88 \%$ ).

\section{DISCUSSION}

\section{The limitations of this study}

In this study period, there were 28 RMS patients who satisfied the inclusion and exclusion criteria. Unfortunately, 2 patients could not be included in the analysis because of incomplete examination. This diagnostic test study actually requires at least 26 patients for each sensitivity and specificity test. The limitation of the sample size would lower the confidence interval of the diagnostic indices. If the result of this study will be applied in the community population, then another study with $95 \%$ confidence level and narrower total width of confidence interval should be performed.

\section{The patients' profile}

The average age of RMS patients was 13.5 year and the youngest patient was 10 years old. In Asia and Africa, RMS can occur in patients of less than 20 years old, ${ }^{16}$ moreover it has been reported in patients as young as 5 years old. ${ }^{17}$ In contrary to the western literature that reported female predominance, sex ratio in this study was near equal or male was slightly predominant. The male and female ratio were $1.1: 1$. It agreed with the male predominance reported in a series of RMS patients undergoing Balloon Mitral Valvuloplasty in the Harapan Kita Cardiac Center. In Harapan Kita patients, the male and female ratio was $1.3: 1 .^{18}$ It is also in accordance with Cherian report that in the developing countries RMS occurs in male and female near equally. ${ }^{19}$

In this study, there was no patient suffering from severe anemia that may influence the cardiovascular system. The cardiac output will continuously increase if the haematocrite level is less than 25 volume $\%,{ }^{20}$ the haemoglobin level is less than $7 \mathrm{~g} / \mathrm{dl}$ or half of normal value. ${ }^{21}$ None of our RMS patients showed such haematological abnormalities.

\section{The ECG}

The right axis deviation (RAD) was found in 14 patients, 8 of them suffered from severe RMS. In this study all patients who showed RAD, also showed RVH. RAD is generally found in RVH. ${ }^{22}$

Atrial fibrillation was found in 3 patients. This is in accordance with the literature that atrial fibrillation is rare in children and young people. ${ }^{5}$ 
In contrast to CXR examination that showed 26 patients with left atrial enlargement (LAE), electrocardiographically LAE was found only in 21 patients. This confirmed the literature report that ECG examination in RMS patients would disclose LAE in about $90 \%$ of the cases. ${ }^{11}$

Right atrial enlargement which was seen as $\mathrm{P}$ pulmonal wave was found in 9 patients. The $P$ pulmonal wave was associated with increased pulmonary resistance.

Right ventricular hypertrophy (RVH) was found in 15 patients. RVH was associated with severe RMS ${ }^{23}$ and pulmonary hypertension. ${ }^{7,8}$ Nevertheless, the absence of RVH does not exclude recently developing severe pulmonary hypertension. ${ }^{8}$

\section{The CXR}

Left atrial appendage (LAA) enlargement was found in 18 patients. The LAA enlargement was a pathognomonic sign of mitral valve disease due to RF. ${ }^{4,24}$ The left atrial enlargement (LAE) was found in 26 patients. This confirmed the literature report that LAE was found in most RMS patients. ${ }^{4}$

Left ventricle enlargement was found in 15 patients who showed mild mitral regurgitation in Doppler echocardiography.

Right ventricular enlargement was found in 21 patients who showed either moderate or severe pulmonary hypertension. The right ventricle does enlarge in pulmonary hypertension. ${ }^{5,7}$

The moderate and severe pulmonary hypertension features were found in 13 and 11 patients.

\section{The echocardiography}

The RMS severity was evaluated on basis MVA measurement in $2 \mathrm{D}$ echocardiography examination in adult patients. There is no classification of RMS severity based on children MVA currently. We applied the adult criteria in children.

In children, MVA $\left(\mathrm{cm}^{2}\right)$ correlates well with body surface area (BSA, in $\mathrm{m}^{2}$ ) which is formulated as MVA $=4.83 \times \mathrm{MVA}-0.07 .{ }^{25}$ The predicted MVA of RMS patients in this study will be 4.11 to $6.91 \mathrm{~cm} 2$. Normal adult MVA is $4-6 \mathrm{~cm} 2$. The predicted MVA was slightly larger than normal adult MVA.
The RMS severity prediction by RVH and RAD on ECG

RVH is caused by pulmonary hypertension ${ }^{5,7,26}$ and is found in severe RMS. ${ }^{23}$ However, the absence of RVH does not exclude severe pulmonary hypertension. ${ }^{8}$ The purpose of including RAD as one criteria in the prediction of severe RMS was to increase specificity and accuracy. If the RVH was used alone, it would give a specificity of $62.5 \%$ and an accuracy of $73.1 \%$, while the combination would give $75 \%$ and $76.9 \%$ respectively.

In this study, sensitivity of RVH and RAD was $80 \%$ (c.i. $90 \%: 65 \%$ to $90 \%$ ), specificity was $75 \%$ (c.i. $90 \%$ : $59 \%$ to $86 \%$ ). Negative predictive value was $85.7 \%$ (c.i. $90 \%: 71 \%$ to $94 \%$ ). This means that if there is no RVH and RAD on ECG examination in RMS patients, then RMS is most probably not severe.

\section{The RMS severity prediction by CXR analysis}

Pulmonary hypertension occurs in moderate or severe RMS. In moderate RMS, upper pulmonary lobe receives more blood perfusion than normal, so the upper pulmonary blood vessels appear to fill equally to blood vessels of the lower lung field. In severe pulmonary hypertension, the upper pulmonary lobe receives more blood than lower lobe. These pulmonary vascular changes are seen in the CXR. ${ }^{5-7,27}$ The degree of pulmonary hypertension can be used to assess the severity of RMS. ${ }^{6}$

Sensitivity of CXR in the prediction of RMS severity was $80 \%$ (c.i. $90 \%$ : $65 \%$ to $90 \%$ ), specificity was $81.2 \%$ (c.i. $90 \%: 66 \%$ to $91 \%$ ). Negative predictive value had highest diagnostic value, i.e., $86.7 \%$ (c.j. $90 \%: 72 \%$ to $94 \%$ ). This means that if there is no severe RMS sign on CXR film in RMS patient, then the RMS is most probably not severe.

The RMS severity prediction by ECG or CXR analysis

The RMS prevalence is relatively rare amongst RHD patients, i.e., about 5-10\%. ${ }^{5,6}$ In Pediatric Cardiology sub-division Child Health Department, the RMS prevalence is also rare. In this study, there were only 28 patients out of approximately 400 RHD patients examined. To screen RMS patients in the rural area, a sensitive diagnostic test is required to support clinical examination. 
The ECG and CXR analyses were combined to increase the sensitivity. If either ECG or CXR analysis showed severe RMS sign, then the patients were grouped as severe RMS. The results are shown in table 7 .

The sensitivity of combined examination was higher (90\%) than the sensitivity of ECG $(80 \%)$ or CXR analysis $(80 \%)$ alone. The negative predictive value was also increased to $92 \%$, in contrast to $85.7 \%$ in the ECG and $86.7 \%$ in the CXR analysis. The accuracy of combined examination was equal to the accuracy of ECG but slightly lower than the CXR analysis. The other diagnostic indices had lower value than ECG or CXR analysis. This might be caused by the increase of false positive cases and decrease of true negative cases.

\section{CONCLUSION}

The RMS severity criteria on CXR analysis and ECG examination are useful in predicting the RMS severity, especially in rural area where echocardiography facility is lacking. It may be beneficial in managing RMS patients especially in screening severe RMS patients for referral. To determine the indication for an invasive procedure, more accurate diagnostic procedure is needed such as echocardiography, which can be performed in the referral hospital.

\section{REFERENCES}

1. Lokakarya Masalah Demam Reumatik dan Penyakit Jantung Reumatik : Rumusan hasil lokakarya. Dalam:Laporan Lokakarya Masalah Demam Reumatik dan Penyakit Jantung Reumatik di Indonesia. Jakarta: Asian Society of Pediatric Cardiology dan Bagian Kardiologi FKUI/RSJ Harapan Kita, 1988;1-18.

2. Markowitz M, Gordis L, eds. Chronic rheumatic heart disease. In: Rheumatic fever. 2nd ed. Philadelphia: Saunders, 1972;186-93.

3. Kaplan S. Chronic rheumatic heart disease. In: Adams FH, Emmanouilides GC, eds. Moss' heart disease in infants, children, and adolescents. 3rd ed. Baltimore: Williams \& Wilkins, 1983;552-65.

4. Elliott LP. Use of chest film in rheumatic mitral valve stenosis. In: Taveras JM, Ferrucci JT, eds. Radiology Diagnosis-Imaging-Intervention. Vol 2. Philadelphia: Lippincott, 1986;1-6.

5. Sukumar IP. Mitral stenosis. In: Anderson RH, Shineboume EA, Macartney FJ, Tynan M, eds. Pediatric cardiology. Edinburgh: Churchill Livingstone, 1987;1 198-204.

6. Nadas AS, Fyler DC, eds. Acute rheumatic fever and rheumatic heart disease. In: Pediatric cardiology. 2nd ed. Philadelphia: Saunders, 1972;141-81.

7. Kaplan S. Chronic rheumatic heart disease. In: Adams FH, Emmanouilides GC, Reimenschneider TA, eds. Moss' heart disease in infants, children, and adolescents. 4th ed. Baltimore: Williams \& Wilkins, 1989;705-18.

8. Sokolow M, McIlroy MB, Cheitlin MD. Mitral valve disease. In: Clinical cardiology. 5th ed. Norwalk: Prentice-Hall International, 1990;377-91.

9. Browner WS, Black D, Newman TB, Hulley SB. Estimating sample size and power. In: Hulley SB, Cummings SR, eds. Designing clinical research. Baltimore: Williams \& Wilkins, 1988; 139-50.

10. Braunwald E, ed. Assessing cardiovascular disability. In: Heart disease. 3rd ed. Philadelphia: Saunders, 1988;11- 2.

11. El-Said GM, El-Refaee MM. Rheumatic mitral stenosis. In: Garson A, Bricker JT, McNamara DG, eds. The science and practice of pediatric cardiology. Vol. 2. Philadelphia: Lea and Febiger, 1990;1506-11.

12. Braunwald E, ed. Mitral stenosis. In: Heart disease. 4th ed. Philadelphia: Saunders, 1992;1007 - 17.

13. Braunwald E, ed. Mitral stenosis. In: Heart disease. 3rd ed. Philadelphia: Saunders, 1988;1023-34.

14. Purwohudoyo SS. Pembesaran jantung dan penelitiannya. Dalam : Pemeriksaan kelainan-kelainan kardiovaskular dengan radiografi polos. Jakarta : Penerbit Universitas Indonesia, 1984;17-31.

15. Berry CC. A tutorial on confidence intervals for proportions in diagnostic radiology. AJR 1990;154:477-80.

16. Gotsman MS, Van der Horst RL. Surgical management of severe mitral valve disease in childhood. Am Heart $J$ 1975;90: 685-7.

17. Taranta A, Markowitz M, eds. Etiology and epidemiology. In: Rheumatic fever. 2nd ed. Dordrecht: Kluwer Academic Publisher, 1989;10-8.

18. Harimurti GM, Haryono N, Rachman OJ, Yusak M, Roebiono PS, Rahayoe AU, et al. Juvenile mitral stenosis. Balloon valvuloplasty (Abstract). Asian Congress of Pediatric Cardiology, Kuala Lumpur 1992.

19. Cherian G, Vytilingam KI, Sukumar IP, Gopinath N. Mitral valvotomy in young patients. Br Heart J 1964;26:157-66.

20. Grossman W, Braunwald E. Anemia. In: Braunwald E, ed. Heart disease. 3rd ed. Philadelphia: Saunders, 1988;781-3.

21. Fowler NO. Anemia. In: Hurst, ed. The heart, arteries and veins. 6th ed. New York: McGraw-Hill, 1986;399-400.

22. Park MK, Guntherorth WG. Hypertrophy. In: How to read pediatric ECGs. Chicago: Year Book Medical Publisher, 1988; 50-68.

23. Wood $P$. An appreciation of mitral stenosis. Investigations and results. Br med J 1954;1:1113-24.

24. Kelley MJ, Elliott LP, Shulman ST, Ayoub EM, Victorica BE, Gessner IH. The significant of the left atrial appendage in rheumatic heart disease. Circulation 1976;54:146-53.

25. Riggs TW, Lapin GD, Paul MH, Muster AJ, Berry TE. Measurement of mitral valve orifice area in infants and children by two-dimentional echocardiography. J Am Coll Cardiol 1983;3:873-8.

26 Rackley CE, Edwards JE, Karp RB. Mitral stenosis. In: Hurst JW, ed. The heart, arteries and veins. 6th ed. New York: McGraw-Hill, 1986;754-64.

27. Kelley MJ, Jaffe CC, Kleinman CS. The chest radiograph. In: Cardiac imaging in infants and children. Philadelphia: Saunders, 1982;55-89. 